\title{
THE WRITING OF POLITICS AND THE POLITICS OF WRITING IN HELEN MARIA WILLIAMS' A TOUR IN SWITZERLAND (1798)
}

\author{
Paula Yurss Lasanta \\ Universitat Autònoma de Barcelona
}

\begin{abstract}
British author and political activist Helen Maria Williams (1759-1827) dedicated the greatest part of her career to describe and analyse the French Revolution and the consequences of its aftermath. She is known for her Letters written in France (1790), an eyewitness account of her first visit to France. At the beginning of her career, Williams was praised in Britain for her sensibility poems. However, when she moved to France, and especially after the publication of A Tour Switzerland (1798), she shows her commitment to the ideas of the French Revolution while presenting her writing a source for accurate political and historical information. For this aim, she employs a series of strategies that situate herself in the position of an informed intellectual. This article focuses on A Tour in Switzerland, a work that has received less critical attention than Letters but deserves reconsideration.
\end{abstract}

Keywords: Helen Maria Williams, women's writing, 18th century, French Revolution.

\section{Resumen}

La autora y activista política británica Helen Maria Williams (1759-1827) dedicó la mayor parte de su carrera a describir y analizar la Revolución Francesa y sus consecuencias. Es conocida por su obra Letters written in France (1790), un testimonio de su primera visita a Francia. Al principio de su carrera, fue elogiada en Gran Bretaña por sus poemas de sensibilidad. Sin embargo, cuando se traslada a Francia, y especialmente tras la publicación de A Tour in Switzerland (1798), muestra su compromiso con las ideas de la Revolución Francesa mientras presenta sus obras como fuentes de rigurosa información política e histórica. Con este propósito, emplea una serie de estrategias para situarse en la posición de una intelectual informada. Este artículo se centra en $A$ Tour in Switzerland, una obra que ha recibido menos atención que Letters por parte de la crítica pero que merece ser reconsiderada.

Palabras clave: Helen Maria Williams, escritura femenina, siglo XVIII, Revolución Francesa. 


\section{Introduction}

On March 1798, the French army occupied Switzerland marking the end of the Old Swiss Confederacy and the beginning of the new Helvetic Republic. Only a few weeks before this episode, British author Helen Maria Williams released her A Tour in Switzerland (1798). As explained by Deborah Kennedy, this timing "automatically and deliberately involved the book in the politics of the moment" (128). Regardless of the fact of being largely ignored or marginalized by the critics when compared to Williams' Letters written in France (1790), A Tour in Switzerland is compelling inasmuch as is it offers the reader something more than a travel narrative. In this book, Williams recasts as a travelogue the diary that she kept in her six-month stay in Switzerland in 1794. The outcome is eclectic since it combines political analysis and journalism with travel anecdotes and a romantic description of alpine landscapes. Elizabeth Fay writes that travel literature was a genre that allowed the author to show her or his literary skills from the safe position of an amateur rather than an authority or scholar (7). In this case, Williams is far from presenting herself as an amateur since she adopts the position of an intellectual who is informed about the political debates of her time. After her journey across Switzerland, Williams ceases to put herself in the position of a spectator of her previous works in order to adopt the viewpoint of a political reporter. Here, Williams unfolds her critical thinking more than in any of her previous tracts. In the chapters devoted to political analysis, Williams displays a method of gathering, interpreting and presenting information that situates her in a position of authorial control. Deborah Kennedy argues that "by the middle of the 1790s, Williams had attained an unprecedented position for a woman writer by becoming a well-known authority on an international event of immeasurable historical importance" (122). In A Tour in Switzerland, Williams wields this reputation with decisiveness and presents herself as a political analyst.

In the eighteenth century Williams was a respected figure in the revolutionary francophone circles. Her work was complimented by figures such as Elizabeth Montagu, Samuel Johnson, Dorothy and William Wordsworth, Mary Wollstonecraft, Hester Piozzi or Alexander von Humboldt. Born from a Scottish mother and a Welsh father in 1761, she received a presbyterian upbringing. After moving to London in 1781, Williams and her family became members of the congregation of the Reverend Dr Andrew Kippis, who praised her poetry and introduced her to the dissenting literary circles. She published her first poetry works in her early twenties, Edwin and Eltruda (1782), Peru (1784), and Ode to the Peace (1786). Williams already starts to express her political curiosity by appealing to strong emotions when she articulates her political ideas. These early sensibility poems were received favourably, and her next publication, Poems (1786), gathered around 1500 subscribers. In 1790 she published her first and only novel Julia, a Novel Interspersed with some Poetical Pieces (1790) which was inspired by Rousseau's Julie ou la Nouvelle Héloüse (1761). This novel does not address political issues directly, but it includes a poem "La Bastille: A Vision", which is representative of Williams' interest in 
the French Revolution. As a result of her support for revolutionary ideas, coupled by her admiration for French literature, she would travel to France that same year. She recounted the events that she witnessed in her acclaimed work Letters Written in France. In 1792, she established herself in France accompanied by her mother and sister. In the second volume of her Letters, published in 1794, she starts to detach her arguments from the literature of sensibility. She gradually starts to portray herself as an informed and intellectual writer. This renders her work not merely literary, but also journalistic and philosophical, which becomes particularly evident in A Tour in Switzerland.

Despite the significance that Williams' writings on the French Revolution had in Britain at the end of the eighteenth century and at the beginning of the nineteenth, scholars have devoted scant attention to her contribution to both history and political thought. Several studies on Williams have studied her role as a sensibility writer, paying attention mainly to her literary style, while other scholars have focused on her biographical aspects and connections. This is the case of the only monograph dedicated to Williams, Helen Maria Williams and the Age of Revolution (2002), written by Deborah Kennedy. This work is a good starting point to address Williams' corpus on the whole but it fails to provide a thorough analysis of each of her works. Williams is known mainly for her Letters Written in France (1790), which has been treated as representative of her political discourse, while the way in which her political thinking evolved over time is overlooked. In "From Liberty to Lechery Performance, Reputation and the "Marvelous Story" of Helen Maria Williams (2010)" Louise Duckling recognises that Williams established "her own brand of political philosophy" (74). However, the article only deals with the first volume of Letters, even though, only in the 1790s, she published eight volumes of her experience in France.

Williams has left us an extensive literary legacy. As a poetess, her numerous poems of the 1780s and two books of poems, Poems (1786) and Poems on Various Subjects (1823), stand out. Besides, she created twelve volumes dedicated to the historical and political analysis of Revolutionary events between 1790 and 1827. She also worked as a translator, producing the first translation into English of Bernardin de Saint Pierre's Paul et Virginie (1795) and Alexander Von Humboldt's Researches (1814) and Personal Narrative (1814-26), which consists of seven volumes. Her only travel narrative, A Tour in Switzerland (1798), has received, as stated before, little critical attention. In her book published in 2013, entitled Revolutionary Women Writers, Charlotte Smith \& Helen Maria Williams, Angela Keane dedicates one chapter to A Tour in Switzerland. This short chapter contains an overview of the whole two volumes, and it discusses its main themes -sublime experience, politics, exile...- without pausing to offer a more detailed analysis of its intellectual elements. Besides, this book is also representative of what has been stated in the previous paragraph since in its section dedicated to Letters from France, Keane writes that "the first volume [...] is the main focus of my discussion" (99). Chris Jones" "Travelling hopefully: Helen Maria Williams and the feminine discourse of sensibility" 
(2000) focuses on Williams' chronicles of France. Although it is published in a volume about travel writing, it is centered on Williams' sensibility and romantic rhetoric elements and her experience of the contemplation of nature. Helen Maria Williams' writings deserve reconsideration from the viewpoint of her engagement in the intellectual debate of her time. This is particularly urgent in the case of A Tour a Switzerland, which is rarely chosen as an object on analysis by scholars who explore Williams' writing.

In the first part of this article, I place Williams' A Tour in Switzerland in relation to the works of other contemporary authors with the aim of providing the context of its publication. The second part is dedicated to analyse Williams' engagement with political writing and the strategies that she uses to convey her arguments in an effective way. Likewise, I take into consideration similar strategies that she had employed with the same intention in previous publications. In the third part, I explore how Williams constructs an account of herself as an intellectual by showing awareness of recent publications and aligning her writing with a philosophical approach. At the same time, I draw attention towards Williams' self-fashioning as a philosophical writer. Following that, I interrogate how Williams' gender shaped the reception of A Tour in Switzerland at the moment of its publication.

\section{The Controversy in Britain surrounding the Revolution}

Both Helen Maria Williams' Tour and her chronicles of the French Revolution were published amidst all the political fervour in Britain surrounding the French Revolution. Letters from France was published in the same year as Edmund Burke's Reflection on the Revolution in France (1790). As opposed to Williams, Burke positioned himself against the revolution and he aimed to convince the British readership of its pernicious influence. Mary Wollstonecraft replied to Burke's conservatism with her Vindication of the Rights of Men (1790). Another woman writer who challenged Burke was Catharine Macaulay with her Observations on the Reflections of the Rt. Hon. Edmund Burke, on the Revolution in France (1790). Macaulay wrote mainly historical texts and was an open supporter of revolutionary causes. Anna Laetitia Barbauld, who had traveled to France shortly before the Storming of the Bastille, wrote An Address to the Opposers of the Repeal of the Corporation and Test Acts "roused by Edmund Burke's attacks on the French Revolution" (McCarthy). Barbauld and Williams had been raised in dissenting households and Williams was an admirer of her work to the extent that she quotes her Epistle to William Wilberforce on the Rejection on the Bill for Abolishing the Slave Trade (1791) in A Tour in Switzerland. Barbauld's Epistle and Williams' Poem on the Bill Lately Passed Regulating Slave Trade (1788) show the commitment of these two authors to the abolitionist movement. In 1791, one of the most influential responses to Burke was published, Thomas Paine's Rights of Man. Paine had become a strong advocate for the American independence, a cause that Williams also supported. Not surprisingly, they now also shared their defense of the French Revolution. In 
the same way as Williams, Paine would also travel to France during the Revolution. When compared to Burke's Reflection, Williams' Vindication, Macaulay's Observations and Paine's Rights of Man, Williams's writing is original in that she does not frame her arguments as a reply to Burke, thus showing initiative as a political writer. While the works mentioned were published as political tracts, Williams published her account of the French Revolution as an epistolary exchange not devoid of political analysis. In her Letters, Williams adopts the perspective of an eye-witness as means to ensure the accuracy of her chronicles. In 1792, Wollstonecraft would also travel to Paris. As Janet Todd indicates in Mary Wollstonecraft: A Revolutionary Life, they both attended the same revolutionary salons, and Wollstonecraft became "a firm friend" of Williams (212). Wollstonecraft published An Historical and Moral View of the French Revolution; and the Effect It Has produced in Europe (1794) in the same year that Williams travelled to Switzerland. Wollstonecraft's work is of a less heterogeneous nature and focuses on historical and political analysis, while Williams combines this aspect with other subjects as I have already indicated. Although the authors mentioned above continued to show interest in the Revolution, Williams devoted almost her entire career to the political analysis of revolutionary events and she went on to write about it well into the nineteenth century. Her last work, entitled Souvenirs de la Révolution Française was published on the year of her death (1827), which confirms her commitment to the cause until the last days of her life.

\section{Politics and the Writing of Informed Observation}

In 1793, during the Jacobin's time in the French government - known as "the reign of terror"- Williams' home was searched on a few occasions. At that time, she was settled in Paris and had already become a well-known figure in the Girondine circles. In September the "Law of Suspects" ordered the incarceration of all suspected counter-revolutionaries. As with all British citizens residing in France, Williams was imprisoned for a short period of time. Fearing further retaliations, Williams travelled to Switzerland the following year together with friend and life companion John Stone. During the six months that she stayed in Switzerland, she kept a detailed diary in which she records not only her travel anecdotes and impressions of the country, but also an study on how Swiss governments operated in each canton. Her previous chronicles of the French Revolution were criticized, in Jacqueline Leblanc's words, for "lacking serious critical perspective" (26) something that Leblanc agrees with. In similar terms, Angela Keane suggests that Williams' early works are lacking in "depth and variety in social discourse" (87). Maybe in order to prevent a negative reception based on the superficiality of her political ideas, Williams claims political and historical authority by presenting her writing as the result of detailed observation: "I made a number of notes of what I had myself seen" (A Tour in Switzerland Vol II 10), and the subsequent reworking of these notes. She writes the final version of the Tour four years after her visit, going over her initial diary, which becomes both a journalistic and intellectual task. She registers the 
conversations that she held with different inhabitants of the country from different social classes that allow her to form a complete picture of the social and political structure. Besides, she describes her visits to Swiss libraries and her interviews with intellectual figures which give her access to detailed and accurate political and historical data. Such an attitude is also reflected in the work's formal structure. A Tour in Switzerland is the first non-narrative prose writing by Williams in which she does not make use of the epistolary form. Williams wants to distance her personal emotions from her political passages since her way of writing was well-known in Britain for the intense subjective feeling of her early literary career. She chooses to organise her Tour in different chapters in which she includes a subtitle with the different topics that she deals with in each section. In this manner, the book follows an encyclopedic structure in which the reader can easily access specific information. The aim of this is to create a work that appears to be informative and objective.

Chapter One opens with Williams' strong criticism of the Jacobin regime calling it a "new species of tyranny which assumed the name of revolutionary government" (A Tour in Switzerland Vol I 1). From the very beginning Williams takes an overtly political position and repudiates a form of government that she considers violent and repressive. This strategy already appears in the second volume of Letters (1794) when she opens the first letter with a harsh criticism of the Commune Provisoire:

While the real patriots of France ... risked their lives ... and by their desperate valour confirmed the liberty of their country, a set of men ... contrived ... to seize upon a considerable portion of power; and never surely in the annals of tyranny have we heard of power more shamefully abused ... The short period of their usurpation, committed more crimes than despotism itself would have achieved in ages. (Vol II 2-3)

Here, Williams rallies against the Jacobin leaders by portraying them as being more oppressive than the despotism they initially fought against. In the same way, they are defined as a 'set of men', a small group that rules over the majority of people, who are considered by Williams the 'real patriots'. Williams always defended the Revolution as a necessary step to attain freedom and social equality, but this does not prevent her to be critical towards those who had misused it. In these lines, she reinforces her belief in freedom as the ultimate achievement of the Revolution. In the case of A Tour in Switzerland, Williams goes a step further by presenting herself as a political fugitive, which she uses to ensure the readership that her account is verifiable. This strategy is already evident in her preface to her translation of Paul et Virginie, published in 1795 after her return from Switzerland. Here she writes that amidst the "Jacobinical despotism, which, while it murdered in mass, persecuted in detail, the resources of writing, and even reading, were encompassed with danger" (Vol I iii). Williams' escape to Switzerland is not only due to the fact that she finds herself in a risky situation, she also wants to arrive at a place where she can perform her profession as a writer as well as have access to reading and study. She is thus 
presenting herself as being committed to her writing of political denunciation. Significantly, in Tour, she claims that the political pressure that she underwent the year before was not due to her political affinities only but also to her flagrant denunciation of the current political affairs through her writing:

I was not merely involved in the common danger which threatened every individual in France, but had claims to particular proscription. It was not only remembered by many of the satellites of Robespierre, that I had been the friend of the Gironde, of Madame Roland, martyred names which it was death to pronounce, but that I had written a work, published in England, in which I traced, without reserve, the characters of our oppressors. (Vol I 1-2)

In this passage Williams is claiming her proximity to Madame Roland, a key figure in Girondine politics, and, as a result, she is implying her own relevance and involvement in the same cause. At the same time, she highlights the repercussion of her own writing. She puts herself in the position of an influential writer whose political opinions are not only heard by the public but that also provoke distress in the current government. In this way, Williams presents her writing as a political act in itself. What is more, she points to her previous writing as one of the first texts to present and condemn the situation while providing a faithful description of the political events: "No danger could be more imminent than that of living under the very tyranny which I had the perilous honour of having been one of the first to deprecate, and to proclaim" (A Tour in Switzerland Vol I 2). According to her own words, her chronicles were a first-hand narration of the political situation in France, and the reader may expect to find the same about Switzerland in the present work. In these passages she suggests that rather than having merely artistic interests, she acts in the manner of a journalist. Besides, she also wants to make certain that her readership does not take this book as the telling of a pleasure trip. Switzerland had become in the eighteenth century an obliged destination for the Grand Tour. Although Williams sometimes adopts the position of a traveller, especially when she describes the powerful effects that the contemplation of nature has in her writing, she reaffirms that the reasons for her travel are political. Not only the purpose of her travel is connected to the political events, but also the publication of the work itself: "It is the present moral situation of Switzerland that justifies the appearance of these volumes, in which an attempt is made to trace the important effects which the French Revolution has produced in that country, and which are about to unfold a new era in its history" (Vol I 1). This perspective differentiates her Tour from other travel narratives of the time.

Williams' engagement in political analysis is made evident in the structure of her chapters about political organization. Every time she describes her arrival to a new destination in Switzerland, she dedicates a few paragraphs to analyse how the canton is governed. Gary Kelly, Chris Jones and Deborah Kennedy argue that in A Tour in Switzerland Williams participates in a critique of the government of the Swiss cantons in order to defend the necessity of a revolution in this country as means to prove her strong belief in the revolutionary cause 
despite the later events. While I agree with this reading of Williams' work, I would also add that she does not limit herself to participating in the revolutionary discourse but elaborates one of her own. By criticizing the political organization she is also asserting her position as an outspoken reporter, a persona that she keeps throughout the book. As a result, she forcefully criticizes the power structure and employs harsh language such as "usurpation in the eyes of the people" (Vol I 172), "the abuses which exist in these Swiss governments" (Vol I 216); "reins of arbitrary power" (Vol I 216); "the government is nothing but a mere oligarchy, incompatible with every idea of free political institution" (Vol II 58); "civic degradation" (Vol II 58); or "their governors have instituted the most illegal and arbitrary customs" (Vol II 140). However, she does not direct all her criticism to the Swiss. As I have already mentioned, she attacks the jacobin government, that she even labels as "the pestilential reign of terrorism" (Vol II 89). Williams delves into political analysis when she compares the state of affairs in Switzerland and France, both before and after the French Revolution. This comparative slant is one of the characteristics that best differentiates Tour from the rest of her previous work. The subtitles make the comparison clear, for example: "Comparative View of the Spirit of Commerce in France, before, and since the Revolution" or "Comparative View of French and Swiss Peasantry before the Revolution".

In her retelling of her visit to Switzerland, that took place four years before she published her Tour, Williams also adds relevant information in the current state of politics. As a journalist, she goes over her previous notes and brings them up to date. An example of this are the sections dedicated to Napoleon Bonaparte. With these passages, Williams may be showing that she does not only aim to write a mere historical account but a relevant political analysis. At the same time, I believe that Williams is making use of a strategy that she had already employed in her novel Julia (1790) and that Louise Joy explains in her article "Emotions in Translation: Helen Maria Williams and "Beauties Peculiar to the English Language"". In Julia, the narrator is presented as someone observing the scene, in the same way as Williams observes the sociopolitical context both in France and Switzerland, but in this case she also participates in it. According to Joy, even if the narrator uses the present tense, it doesn't narrate its experience with immediacy and it acquires "the stability of a fixed recollection. Crystallized by the passing of time and neatly sculpted into coherent language, it is offered up as an account that bears only one interpretation" (154). Williams goes one step beyond in Tour in Switzerland by using the past tense and distancing herself even more from her experiences in Switzerland that took place four years before. In this way, her intention may be to offer a controlled analysis of the events she describes.

\section{Self-Representation and Reception}

Another strategy used by Williams to assert herself as an authority in political matters is to show that she has read the most recent and influential 
works about Swiss politics. Williams quotes several times the british historian William Coxe's Travels in Switzerland published in 1789, only a few years before Williams started working on her travel diary. However, Coxe's and Williams' renderings of Switzerland are different. One way in which she develops her argument is by challenging Coxe's conservative vision of Switzerland. Coxe admires this country for the peaceful cohabitation of its inhabitants as well as for its strong democratic values. The English saw a connection between their own nation and Switzerland and, in Williams' words, both countries even shared the same heroes: "Tell is in England, as well as Switzerland, the hero of our infancy" (A Tour in Switzerland Vol I 147). In Coxe's Travels, Switzerland is presented as an epitome of freedom and equality, an idea that Williams takes down in her writing. For instance, Coxe praises the city of Basel because its inhabitants are educated and interested in intellectual matters and literature. On the same subject, Williams writes that "whatever were the Halcyon days of taste and learning in the period of Mr. Cox's visit, it is a melancholy fact that his literary spirit has entirely evaporated since his departure" (Vol I 115). Williams, who sometimes tends to subtle irony in her writing, leaves open the possibility of doubting about Coxe's description of Switzerland. She does not hesitate to challenge leading intellectual figures of the eighteenth century, including Rousseau. She writes that "Rousseau had also probably overlooked those inconveniences of Democracy" (A Tour in Switzerland Vol II, 54) after presenting the democracy in Switzerland as a mere illusion, because its rulers were chosen only between a few aristocratic families.

One of the most interesting aspects to look at in order to study Williams' self-representation as an intellectual writer is the shift in Williams' perception of herself. In a letter to her friend Ruth Barlow, written in 1794, the year in which she travels to Switzerland, Williams writes: "Indeed I become every day more philosophical, and perhaps what has hitherto appeared to me the greatest of misfortunes, may prove to be my greatest good" (45). She implies here that with a philosophical thinking and method she can produce her best works. In her personal correspondence, Williams acknowledges that she is embracing a new mode of thinking that is inextricably bound up with an evolution in her style of writing. This becomes evident four years later when she fashions herself a philosopher, a position allows her to question figures such as Coxe or Rousseau as I have already mentioned: "Happily a new era opens to the world; the maddening charm of the poet is at length dissolved by the mild wand of the philosophy, and the heroes meed arises from other exploits than those of multitudes destroyed, and provinces desolated" (Vol II 37).Williams is referring to a time when historical events were narrated by poets and she distances her writing from this historical and even epic tradition. With this quotation Williams places her work in line with this new way of commenting politics, which is much more moderate and objective. By contrast, in Poems, Williams had presented herself in accordance with the past tradition: "To describe an important event with accuracy, and to display with clearness and force the various causes which combined produce it, would require all the energy of genius, and the most glowing colours of imagination" (Vol II 53). In her early poetic works, such as 
Edwin and Eltruda, An Ode to the Peace and Peru, Williams celebrates in a panegyric verse the independence of the New American Nation and highlights the plight of native minorities who seek political liberation. However, the discourse that she employs is different from the one we find in the later volumes of Letters and A Tour in Switzerland. In her early poems, she presents her political arguments as a result of the feelings of the heart, which is characteristic of the literature of sensibility. While she never completely renounces to feelings, in her later prose works Williams pays attention to the context of the events and elaborates her political arguments from there.

In order to reinforce her position as a philosopher, Williams narrates her interview with a renowned Swiss intellectual, Caspar Lavater: "We staid long enough at Zuric to visit its first literary ornament Lavater ... no traveller of any lettered curiosity passes through the town, without paying him the homage of a visit" (A Tour in Switzerland Vol I 66). She presents herself as somebody with 'lettered curiosity', but it is in Lavater's visit to her where she really claims a position as a learned writer. "He came to pay me a visit, which I was taught to consider as an unusual compliment, since it is his general rule not to return the visits of strangers" (Vol I 70). She then continues to explain the conversation that they shared about theology. She emphasizes not only her position as thinker, since she deals with learned matters with an eminent philosophical figure of her time but she highlights that it is Lavater himself who enables this intellectual exchange between the two. Interestingly enough, he made an impression on Williams in that "there was more of feeling than of logic in his conclusion" (Vol I 71), but this does not invalidate her admiration for him as a philosopher, but quite the opposite. Her reputation as a sensibility writer sometimes meant for Williams that her political opinions were dismissed for being articulated on feelings rather than on pure reason. Regardless of the fact that her Tour does not present as many characteristics of the literature of sensibility as her previous works, Williams implies here that feelings are not incompatible with intellectual abilities.

Williams' aim is to demonstrate that she is in the position to contribute to the debates of the current state of political affairs. Yet, some of the readers of her and our time did not recognize Williams' writing as a reliable source of political or historical information. Devoney Looser investigates in British Women Writers and the Writing of History, 1670-1820 women's contribution to historical writing. Looser writes that despite the fact of being undoubtedly taking part in the construction of historical discourse, "what women had to face that men did not, of course, was the "problem" of their sex, assigned by a culture that usually did not imagine for them an equivalent place in history or in history writing" (27). As a matter of course, Williams had to deal with the strong prejudices against women writers in the late years of the eighteenth century, in which Britain was becoming increasingly conservative. This rejection of women's writing was even stronger if they were writing not only about history but also about politics, a topic traditionally restricted to men since it belonged to the public exercise of power. In this work Williams does not present herself as 
being in any inferior position to deal with history or politics on account of her gender, but this is something that affected her reputation as a writer, especially after the publication of $A$ Tour in Switzerland. She had already been the object of satire, as well as other writers such as Laetitia Barbauld or Catharine Macaulay, since the three of them are parodied in the satirical print "Don Dismallo running the literary gantlet" (1790). Although some of the critics received William's Tour favourably, some commentaries insist on a distinction between poet and philosopher while they emphasize their preference for Williams' previous style of writing: "As a poetess Miss Williams attracts us much more than as a politician" (London Review 390). In the same year as the publication of her Tour, Williams was featured in Richard Polwhele's The Unsex'd Females. In a note from that poem the following words can be read: "Helen Maria Williams is doubtless, a true poet. But it is not extraordinary, that such a genius, a female and so young should have become a politician". What these commentaries have in common is their preference for Williams as an artistic writer exclusively and their dismissal for her interest in politics. Looser's analysis goes in this same direction when she notes that still today most women writers "are highlighted as novelist, poets, literary critics and playwrights" (5) while their contribution to other areas of knowledge is overlooked, and, I would add, superficially read. The strong opposition that women had to face in the public opinion may be what Williams considered "the greatest of misfortunes" in her letter to Ruth Barlow.

\section{Marvelous History to Future Times}

A Tour in Switzerland transcends conventional expectations for female writers while fully develops Williams' self-representation as a reporter and political activist. Even though Williams already engages in political writing from the beginning of her literary career, and especially since Letters Written in France, in A Tour in Switzerland she moves a step further by openly presenting her position not as a casual eyewitness but as an intellectual writer who presents a critical reflection of the historical moment she observed. Thus, her Tour detaches itself from the literature of sensibility. This work allows the reader to not think of Williams merely as a travel writer or sensibility poet. Williams consolidates here a role as political analyst that she already pointed to in her first chronicles of the French Revolution. What is compelling of this is that Williams specifies her process of developing this work and how she gathers information from various sources, which becomes an intellectual task. At the same time, she adopts a very assertive tone to claim the relevancy of her work in the political framework of the moment. Williams is aware that she is living a crucial time in history and politics and she wants to have her own voice heard within the latest debate as well as recording the events that she witnesses for future generations: "My narratives make a part of that marvelous history which the eighteenth century has to record to future times, and the testimony of a witness will be heard" (Poems on Various Subjects x) [sic]. In looking back, Williams shows awareness of the fact that she has devoted herself to political writing for the greatest part of her life as she writers in the preface to Poems on Various 
Subjects (1823): "I have long renounced any attempts in verse, confining my pen entirely to sketches of the events of the Revolution" (ix-xx). For most of her career she did not see herself as the complimented poet of sensibility of her early years but as a political commentator, journalist, and therefore, an intellectual. Even though she already saw herself as such before 1798, it is with A Tour in Switzerland that she consolidates this position through her writing of informed observation.

\section{WORKS CITED}

Barbauld, Anna Laetitia. An Address to the Opposers of the Repeal of the Corporation and Test Acts. London: J. Johnson, 1790.

---. Epistle to William Wilberforce, Esq. on the Rejection of the Bill for Abolishing the Slave Trade. London: J. Johnson, 1791.

Burke, Edmund. Reflections on the Revolution in France, and on the Proceedings in Certain Societies in London Relative to that Event in a Letter Intended to Have Been Sent to a Gentleman in Paris. London: J. Dodsley, 1790.

Coxe, William. Travels in Switzerland. In a Series of Letters to William Melmoth, Esq. London: Thomas Cadell, 1789.

Duckling, Louise. "From Liberty to Lechery: Performance, Reputation and the "Marvelous Story" of Helen Maria Williams." Women's Writing 17.1 (May 2010): 74-92.

Fay, Elizabeth A. "Travel Writing". The Cambridge Companion to Women's Writing in the Romantic Period. Ed. Devoney Looser. Cambridge: Cambridge University Press, 2015. 73-87. https://doi.org/10.1017/CCO9781139061315.008

Humboldt, Alexander von. Personal Narrative of Travels to the Equinoctial Regions of the New Continent, During the Years 1799-1804. Trans. Helen Maria Williams. London: Longman et al., 1814.

---. Researches Concerning the Institutions and Monuments of the Ancient Inhabitants of America, with Descriptions and Views of Some of the Most Striking Scenes in the Cordilleras!. Trans. Helen Maria Williams. London: Longman et al., 1814.

Jones, Chris. "Travelling Hopefully: Helen Maria Williams and the Feminine Discourse of Sensibility". Romantic Geographies. Discourses of Travel 1775-1844. Ed. Amanda Gilroy. Manchester: Manchester University Press, 2000. 93-108.

Joy, Louise. "Emotions in Translations: Helen Maria Williams and "Beauties Peculiar to the English Language"". Studies in Romanticism 50.1 (Spring 2011): 145-171.

Keane, Angela. Revolutionary Women Writers. Charlotte Smith \& Helen Maria Williams. Devon: Northcote House Publishers, 2013. 
Kelly, Gary. Women, Writing and Revolution 1790-1827. Oxford: Clarendon Press, 1993.

https://doi.org/10.1093/acprof:oso/9780198122722.001.0001

Kennedy, Deborah. Helen Maria Williams and the Age of Revolution. Lewisburg: Bucknell UP, 2002.

Leblanc, Jacqueline. "Politics and Commercial Sensibility in Helen Maria Williams' Letters from France". Eighteenth-Century Life 21.1 (1997): 26-44.

Looser, Devoney. British Women Writers and the Writing of History: 1670-1820. Baltimore: Johns Hopkins University Press, 2000. PMCid:PMC85689

Macaulay, Catharine. Observations on the Reflections of the Right Hon. Edmund Burke, on the Revolution in France, in a Letter to the Right Hon. the Earl of Stanhope. London: C. Dilly, 1790.

McCarthy, William. "Barbauld, Anna Letitia (1743-1825)." Oxford Dictionary of National Biography. Eds. Matthew and Brian Harrison. Oxford: Oxford University Press, 2004. Web 10 Sept 2016.

<http://www.oxforddnb.com.huntington.idm.oclc.org/view/article/1324 $>$

Paine, Thomas. Rights of Man: Being an Answer to Mr. Burke's Attack on the French Revolution. London: J.Johnson, 1791.

Polwhele, Richard. The Unsex'd Females; A Poem Addressed to the Author of the Pursuits of Literature. New York: WM. Cobbett, 1800 (1798).

Rousseau, Jean-Jacques. Julie, or, the New Heloise: Letters of Two Lovers Who Live in a Small Town at the Foot of the Alps. Trans. Philip Stewart and Jean Vaché. Hanover: University Press of New England, 1997 (1761).

Todd, Janet. Mary Wollstonecraft: A Revolutionary Life. London: Weidenfeld \& Nicolson, 2000.

Williams, Helen Maria. A Tour in Switzerland; or, A View of the Present State of the Governments and Manners of those Cantons: with Comparative Sketches of the Present State of Paris. London: G.G. and J. Robinson, 1798.

---. Edwin and Eltruda. A Legendary Tale. London: Thomas Cadell, 1782.

---. Julia, a Novel; Interspersed with some Poetical Pieces. London: Thomas Cadell, 1791.

---."Letter IV". Four New Letters of Mary Wollstonecraft and Helen M. Williams. Eds. Benjamin P. Kurtz and Carrie C. Autrey. Berkeley: University of California Press, 1937.

---. Letters From France; Containing a Great Variety of Original Information Concerning the Most Important Events that Have Occurred in that Country in the Years 1790, 1791, 1792, and 1793. Dublin: J. Chambers, 1794. 
---. Letters Written in France, in the Summer 1790, to a Friend in England; Containing, Various Anecdotes Relative to the French Revolution; and Memoirs of Mons. and Madame du F-. London: Thomas Cadell, 1790.

---. Paul and Virginia. Translated from the French of Bernadin Saint-Pierre. London: G.G. and J. Robinson, 1795.

---. Peru, a Poem. In Six Cantos. London: Thomas Cadell, 1784.

---. Poems, in Two Volumes. London: Thomas Cadell, 1790.

---. Poems on Various Subjects, with Introductory Remarks on the Present State of Science and Literature in France. London: G. and W.B. Whittaker, 1823.

---. Souvenirs de la Révolution Française. Trans. Charles Coquerel. Paris: Dondey-Dupré, 1827.

Wollstonecraft, Mary. A Vindication of the Rights of Men in a Letter to the Right Honorable Edmund Burke; Occasioned by his Reflections on the Revolution in France. London: J. Johnson, 1790.

---. An Historical and Moral View of the Origin and Progress of the French Revolution; and the Effect in has Produced in Europe. London: J. Johnson, 1794.

Received: 30 September 2016

Accepted: 23 November 2016 